\title{
Notes on the nomenclature of Eublemma pannonica (Freyer, 1840): a rectification and a new subspecies name (Lepidoptera: Erebidae, Eublemminae)
}

\author{
Gergely Katona, Balázs Tóth, Zsolt Bálint \\ Hungarian Natural History Museum, Department of Zoology, \\ H-1088 Budapest, Baross utca 13, Hungary. \\ E-mails:katona.gergely@nhmus.hu,toth.balazs@nhmus.hu,balint.zsolt@nhmus.hu
}

\begin{abstract}
The erebid moth Eublemma pannonica (Freyer, 1840) is a distinctive species of the Pannonian region. The species-group name panonica Freyer, 1840 is an incorrect original spelling what needs a rectification. This spelling has been forgotten until its appearance in the catalogue compiled by Robert W. Poole in 1989 for noctuid names and it is again in use. The other original spelling pannonica Freyer, 1840 is the correct one, what was in general usage until 1989. On the basis of voluminous literature references these spellings are discussed. The name Eublemma panonica ronkayorum Fibiger, Zilli \& Yela, 2010 is a junior homonym of Eublemma ronkayorum Fibiger \& Hacker, 2002, therefore the replacement name, Eublemma pannonica ronkayi nomen novum is proposed for the junior taxon. With three figures.
\end{abstract}

Key words - Albert Kindermann, Christoph Freyer, Imre Frivaldszky, Pannonia, replacement name, Syrmia, Friedrich Treitschke

\section{INTRODUCTION}

Working on the erebid moth Eublemma pannonica (Freyer, 1840), a distinctive species of the Carpathian Basin discovered by Imre Frivaldszky (1799-1870), we found two nomenclatural anomalies to be resolved: (1) The current spelling of the name Eublemma panonica needs rectification; and (2) the name Eublemma ronkayorum Fibiger \& Hacker, 2002 is a senior secondary homonym of the subspecies Eublemma panonica ronkayorum Fibiger, Zilli \& Yela, 2010, and needs a replacement name. The aim of the present paper is to discuss these subjects.

Abbreviations - HNHM = Hungarian Natural History Museum (Budapest, Hungary); ICZN - International Code of Zoological Nomenclature (International Commission of Zoological Nomenclature 1999); ZMUC $=$ Zoological Museum of University Copenhagen (Denmark). 


\title{
NOMENCLATURE
}

\author{
Eublemma pannonica (Freyer, 1840) \\ (Figs 1-3A,B)
}

Anthophila panonica Frivaldszky - Freyer 1840: 67, 165; HeYdenreich 1851: 47; POOLE 1989: 390 (unavailable, incorrect original spelling ICZN Art. 32.4).

Anthophila pannonica Frivaldszky - FreYer 1840: caption for table 330, figures 2, 4; EVERSMANN 1844: 338.

Anthophila kindermanni - BoIsDuval 1840: 174 (junior subjective synonym).

Anthophila lenis Eversmann - ANONymus [1842]: 4; EvERSMANN 1844: 338. Antophila pannonica (Freyer) - LEDERER 1857: 43, 186.

Thalpochares pannonica (Freyer) - Hor NIG 1858: 19; FrIVALDSZKY 1865: 98, 164, plate VII, fig. 12; Aigner 1868: 60; Horváth et al. 1875: 61; AbAFIAigner et al. 1896: 40; STAUDINGER \& REBEL 1901: 228; A BAFI-Aigner 1907: 82, plate 51, fig. 23.

Autophila [!] Pannonica, Friv. - FrivaldSZKY 1859: 26.

Micra lenis (Treitschke-Eversmann) - HERRICH-SCH ÄFFER 1843: 440.

Micra pannonica (Freyer) - HERRICH-SCH ÄFFER 1843: 440, in synonymy of Micra lenis; SPULER 1908: 289.

Porphyrinia pannonica (Freyer) - WARREN 1912: 265, pl. 51e "pannonica"; [Kovács] 1950: 572; KovÁcs 1955: 336; HRUBY 1964: 748; VARGA 1969: 54, fig 63:1; Gozmány 1970: 141, fig. 104B; Forster \& Wohlfahrt 1971: 252, pl. 26. fig. 37.

Eublemma pannonica (Freyer) - HACKER 1989: 330; VARGA 1989: 240; RÁKosy 1996: 283, pl 6, fig. 13; RoNKAY 1997: 63.

Eublemma panonica (Freyer) - FIBIGER \& HACKER 1991: 34; VARGA 2010: 101; ANIKIN et al. 2017: 250; KoçAK \& KeMAL 2018: 221; Sinev 2019: 311.

Eublemma panonicum (Freyer) - KoçAK \& KeMAL 2018: 221; KeMAL et al. 2020: 29 .

In the work of FREYER (1840) the species group name of this taxon is spelled as "Panonica" as the head entry of the description. This spelling is repeated in the table of contents, while the spelling for the figure caption is "Pannonica" (Fig. 1). Freyer did not present any etymology for the name, but attributed the authorship to "Frivaldszky" and indicated that the specimen he illustrated was collected in "Unterungarn" (Lower Hungary). This is a situation pertaining to ICZN Article 32.5.1. How can these two kinds of original spellings be explained? Freyer was the sole writer and illustrator of his own book series (OLIVIER 2000). However the layout was produced from his manuscript by the printer and the index was 
prepared subsequently using the already existing sheets with page numbers. On the basis of this evidence the spelling "Panonica" is likely a printer's error. This is supported by evidence that the other original spelling as "Pannonica" was Freyer's own version, as Freyer himself drew and engraved all the illustrations by his own hands, including the caption for the figures as they appeared on the plates (Fig. 1B).
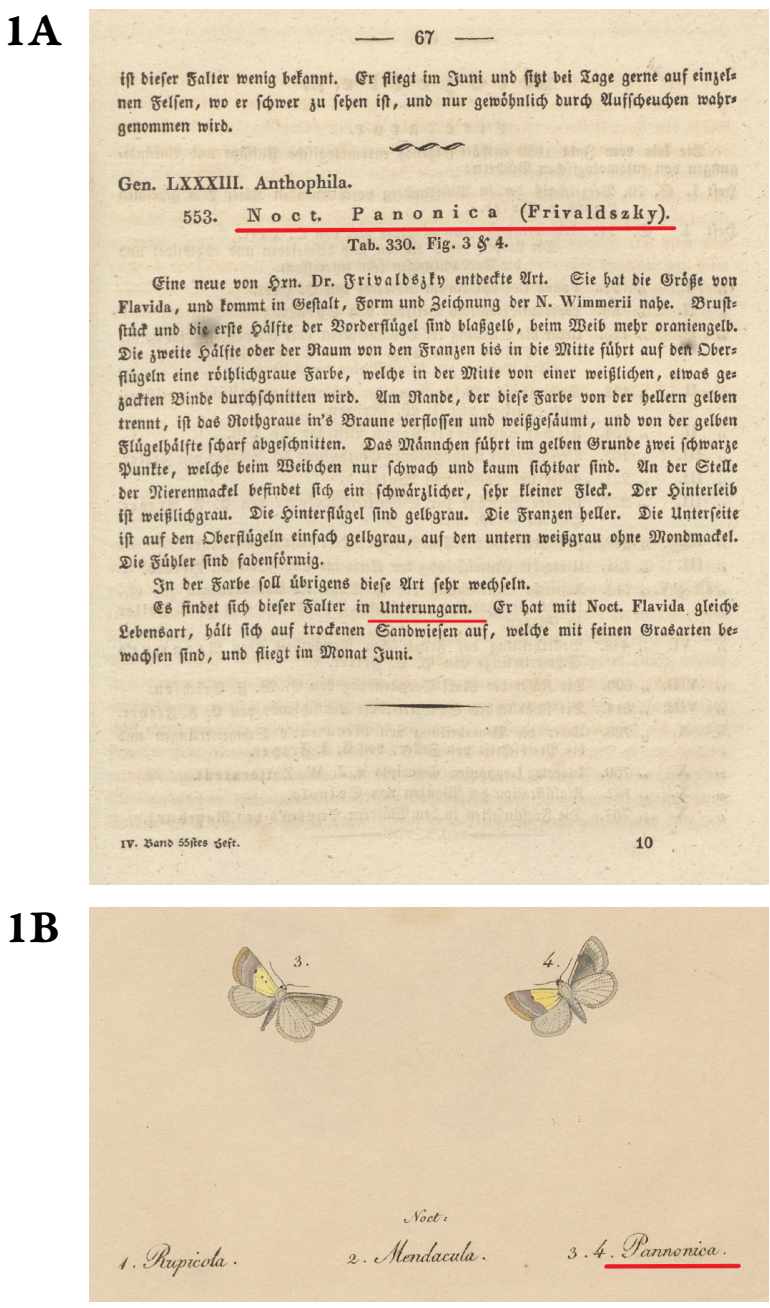

Figure 1. Extracts from the publication of Freyer (1840) evidencing two kinds of original spellings for the species-group name of the species Eublemma pannonica. A = The description of "Noct. Panonica" on page 67; B = figures $3 \& 4$ and their caption in plate no. 330; (words relevant for the present paper underlined by red) (source: Biodiversity Heritage Library) 
The species was probably named after the collecting site of the type material. The collector of the first specimens was most probably Albert Kindermann Jr. (1810-1860), whose father Albert Kindermann Sr. (?-1847) sold this and other newly collected material to contemporary lepidopterists (LEDERER 1875, ABAFIAigner 1899, Olivier 2000). One of his purchasers of Lepidoptera specimens was Imre Frivaldszky (1799-1870), of Pest (Hungary), who sent the newly acquired specimen to Freyer under the name "Pannonica". Another client was Jean Baptiste Boisduval (1799-1879), of Paris (France), who described the species under the name Anthophila kindermanni and indicated the type locality as "Syrmia". This may refer either to the settlement Sirmium (formerly: Szávaszentdemeter, county Szerém, Hungary; now Sremska Mitrovica, Serbia), or to the similarly named region, what is the southerly part of the former Roman province of Pannonia, and lies between the Danube and the Sava rivers. Indeed, in the 19th century, when Latin was still widely practiced, the southern ("lower") part of the Hungarian Kingdom (at present shared by the countries Austria, Croatia, Serbia, Romania and Hungary) was associated with the former Roman province of Pannonia. It was never written with one " $n$ ". The voluminous literature references listed above prove that the spelling "pannonica" was in constant and universal use, and was immediately emended, with the single exception of HEYDENREICH (1851). Although Kindermann collected the first specimens in Pannonia, the life history of the species was studied and examined in detail in the Great Pannonian Plain by I. Frivaldszky (FriVALDSZKY 1859; FrIVALDSZKY 1865; A BAFI-AIGNER 1901; c.f. HOR NIG 1858). In the HNHM there are two original Frivaldszky moths and one caterpillar specimen (Fig. 2).

POOLE (1989), in a bibliographical compilation of noctuid names and their sources, recorded the incorrect original spelling with the erroneous indication that there was no type locality. Since then, "panonica" started to reappear in the literature. Fibiger \& HACKeR (1991) emphasised that panonica was "spelt with only one $\underline{\mathrm{n}}$ at start", without mentioning the other spelling in the original work of what became the common version in subsequent use. PARENZAN et al. (2002) stated, "Secondo Fibiger \& Hacker, (1991) il nome corretto sarebbe panonica, come riportato in Poole (1989), ma lo stesso Freyer nel testo usa il nome pannonica, dalla regione Pannonia, che è stato erroneamente riportato come panonica nella tavola 330." (in our translation = "According to Fibiger \& Hacker (1991) the correct name would be panonica, as reported in Poole (1989), but Freyer himself in the text uses the name pannonica from the Pannonian region, which was erroneously reported as panonica in plate 330."). Unfortunately Parenzan et al. mixed up the location of the two spellings in the original work and, in addition, made a false statement because Freyer did not write "Pannonian region" or anything similar in the text. Moreover, all of their considerations were connected to a specimen of Eublemma cochylioides (Guenée, 1852) misidentified as E. pannonica. 


\section{A}
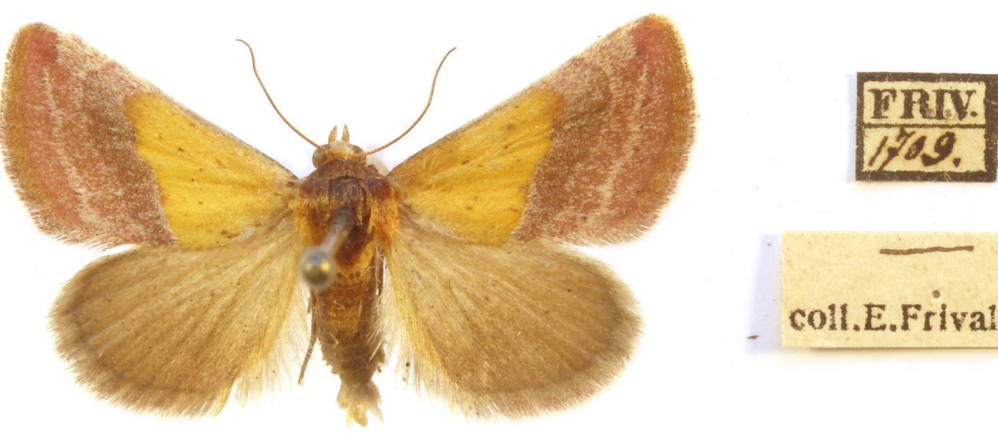

\section{coll.E.Frivaldszky}
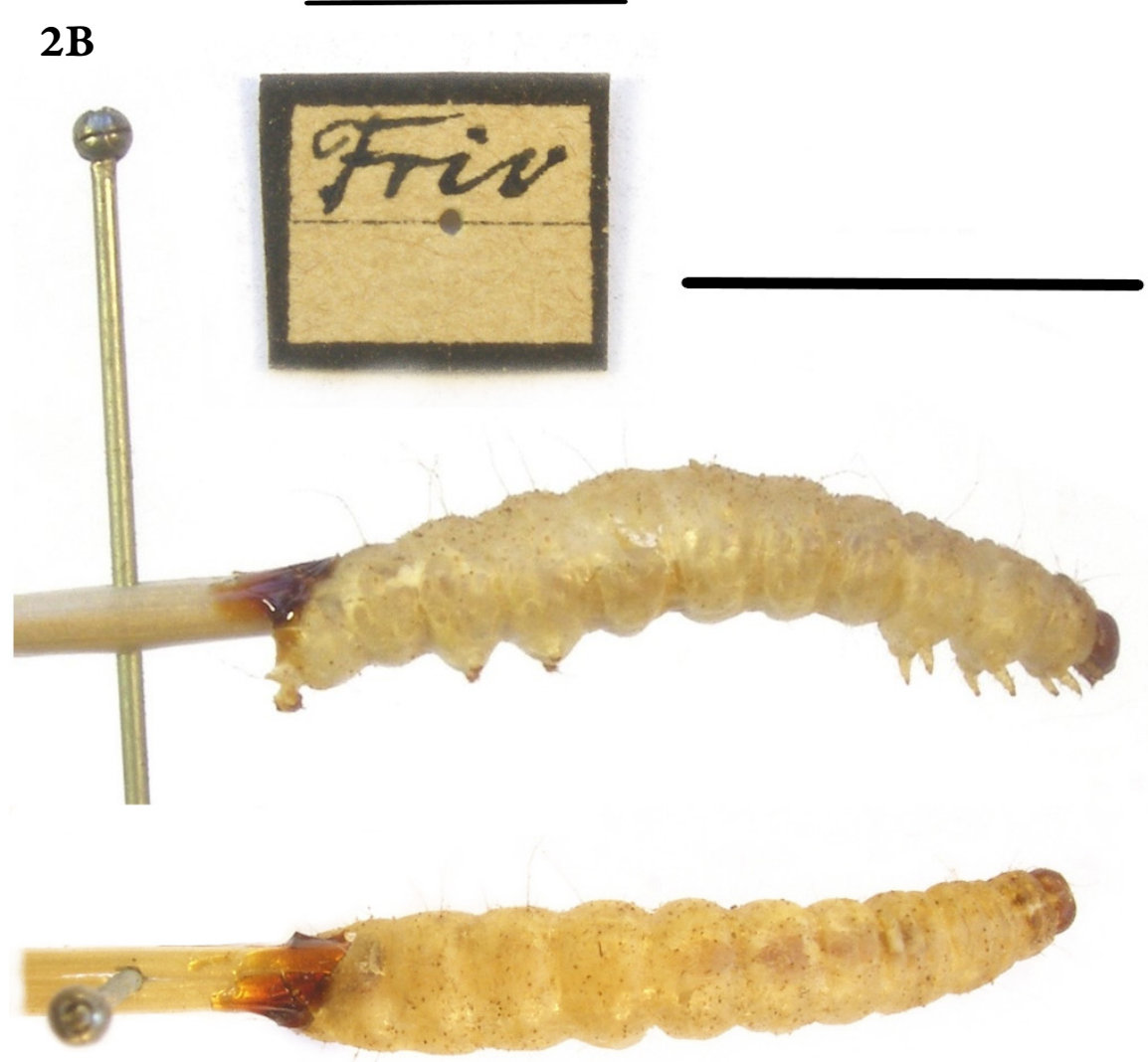

Figure 2. Museum specimens of Eublemma pannonica (Freyer, 1840) with their labels from the Frivaldszky-collection. $\mathrm{A}=$ moth; $\mathrm{B}=$ caterpillar (same specimen in dorsal and lateral view) $($ scale bars $=1 \mathrm{~cm})$ 
VARGA (2010) stated in the English version of his notes presented for "Eublemma panonica" that in first revision of the species Fibiger et al. (2010) had chosen "panonica" versus "pannonica" therefore the former one became the correct spelling. The meaning of the Hungarian version is somewhat different: “A faj nevét a [sic] Freyer a leírás során kétféleképpen betüzte („panonica” versus "pannonica”); a vonatkozó szabályok értelmében az első (ez esetben „hibás”) írásmód az érvényes (lásd Fibiger et al. 2010)." (in our translation = The name of the species was spelled differently by the [sic] Freyer in the original description ("panonica" versus "pannonica"); according to the relevant rules the first - in this case "erroneous" - spelling is the correct one (see Fibiger et al. 2010)." We do not know any rule which states that the first spelling should be the correct one among multiple original spellings. The ICZN Article 24.2.3 implies that the First Reviser is the author who cites all different spellings together and chooses one of them. This act was indeed made by PARENZAN et al. (2002), however, in the result of the misinterpretation of the original article and a misidentified specimen, as we noted previously.

And most recently in their papers some Turkish lepidopterists (KoçAK \& Kemal 2018, Kemal et al. 2020,) give the binomen Eublemma panonicum, using the incorrect original spelling of the species-group name as a neutral noun. The gender of the genus-group name Eublemma is feminine, therefore the usage of panonicum is erroneous (cf. ICZN Art. 30.2).

\section{Eublemma pannonica ronkayi nom. n.}

(Fig.3)

Eublemma pannonica lenis (Eversmann) - HACKER 1989: 330; BÁLINT, GubÁNYi \& Katona 2014: 101 (misidentification).

Eublemma panonica ronkayorum - FIBIGER et al. 2010: 79, pl. 4, figs 29-32, unavailable; junior primary homonym (ICZN Article 57.2.), preoccupied by Eublemma ronkayorum Fibiger \& Hacker, 2002; RoNKAY 2014: 221.

The nominal species "Anthophila lenis" was described by Eversmann (1844) on the basis of an unstated number of specimens with the indication "Habitat circa Sareptam". The name was attributed to Friedrich Treitschke (1776-1842) by the describer. The species was compared to "Anth. pannonica Frivaldsky - Anth. Kindermanni Boisd.", stating that the size of the species was the same "eadem magnitudine, qua praecedens". In the Treitschke collection drawer "HNHM-LEP-05718", housed in the HNHM, there are two "Anthophila" specimens (one male, one female) under the curatorial label "Lenis". These specimens were listed as "Anthophila Lenis" in the document published for the auction of the collection (ANONYMOUs [1842]). They most probably originated from the Kindermann brothers, who collected extensively in the Sarepta region 
already before 1840 (ABAFI-AIGNER 1899). Treitschke identified these specimens representing an undescribed species, named the species and curated the specimens as such. Probably this was communicated to Eversmann by Treitschke himself or by the Kindermanns (see BÁLINT \& Zolot UHIN 2017). Supposedly these specimens are Anthophila lenis syntypes but no evidence can be presented that these specimens have been seen indeed by Eversmann, or the description has been communicated by the Kindermanns or Treitschke on the basis of the specimens found at present in the Treitschke collection. Subsequently, $A$. lenis was considered as a synonym of $A$. pannonica by Frivaldszky, as the identification label on the male specimen "TREITS. [//] 2394." testifies to this (Fig. 3A.). From the beginning of the $20^{\text {th }}$ century to the present days the nominal taxon lenis was considered either as a variation of E. pannonica or E. panonica (STAUDINGER \& REBEL 1905, WARREN 1912, FIBIGER et al. 2010) or a synonym of E. panonica (ANIKIN et al. 2017, SINEV 2019). The name was misapplied by HACKER (1989) in subspecies level for E. pannonica, and this very same taxon was described later as E. panonica ronkayorum in FIBIGER et al. (2010).

The nominal species Eublemma ronkayorum Fibiger \& Hacker, 2002 has been described on the basis of the ZMUC holotype male (type locality: Turkmenistan, $20 \mathrm{~km}$ SE Bairmaim [!] (= Bayramaly), 200-300m) and further 16 paratype specimens collected in Kazakhstan, Tajikistan and Turkmenistan (EBERT \& HACKeR 2002: 263-264). Eight years later the taxon Eublemma panonica ronkayorum has been established on the basis of the holotype male (ZMUC holotype male, type locality: Greece, Crete W, $4 \mathrm{~km} \mathrm{~S}$ Topolia, $350 \mathrm{~m}$ ) (FIBIGER et al. 2010), and further 72 paratype specimens collected in Azerbaijan, Iran, Russia (Daghestan), Turkey, Turkmenistan and Uzbekistan. The two names represent two biological species (Figs 3B-C).

Both names are available having the same spelling as they have been established in combination with the same generic name, thus are primary homonyms (ICZN Article 53.3.) and hence the junior name is permanently invalid (ICZN Article 57.2.). It needs a substitute name as there is no available and potentially valid synonym for the taxon (ICZN Article 60.1.). Therefore we establish the new replacement name Eublemma pannonica ronkayi nomen novum for Eublemma panonica ronkayorum Fibiger, Zilli \& Yela, 2010. The type material of E. pannonica ronkayi is that of what has been fixed for E. panonica ronkayorum (ICZN Article 67.8.) (Fig. 3).

The patronyms of the "ronkayorum" species-group names are the Ronkay brothers (the senior László and the junior Gábor), who study mainly the superfamily Noctuoidea and have described more than thousand species to date. The new replacement name refers solely to Dr László Ronkay, the elder brother, who was working in the HNHM Lepidoptera Collection for more than forty years, serving as lead curator between the period of 1994 and 2010. 


\section{$3 \mathbf{A}$}
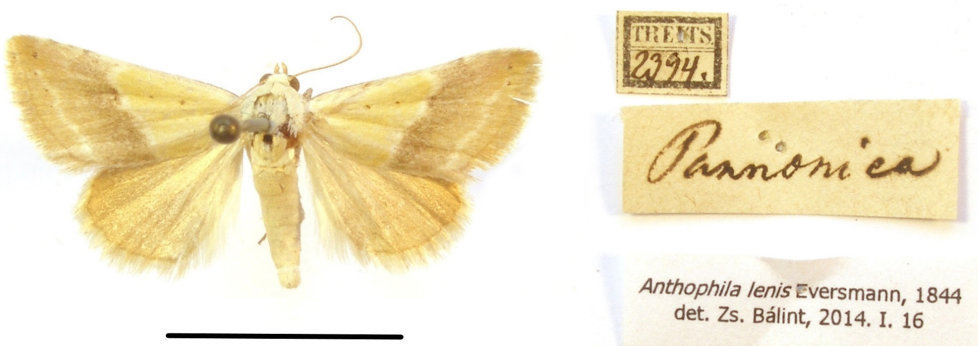

\section{Anthophila lenis Eversmann, 1844 det. Zs. Bálint, 2014. I. 16}

\section{Magyar Természettudományi \\ Múzeum, Lępkegyüjtemény Digitalizálva, 2014}

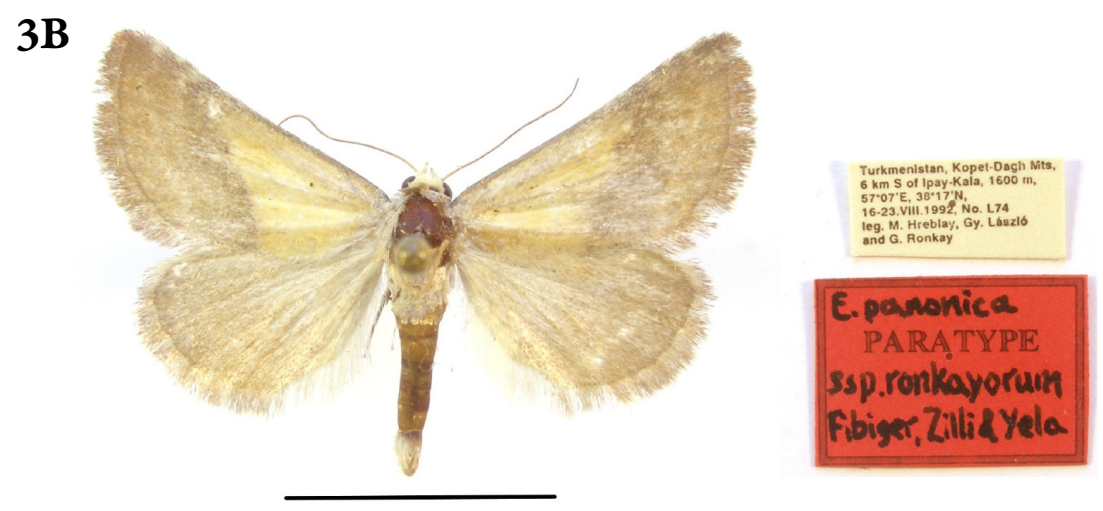

\section{$3 \mathrm{C}$}

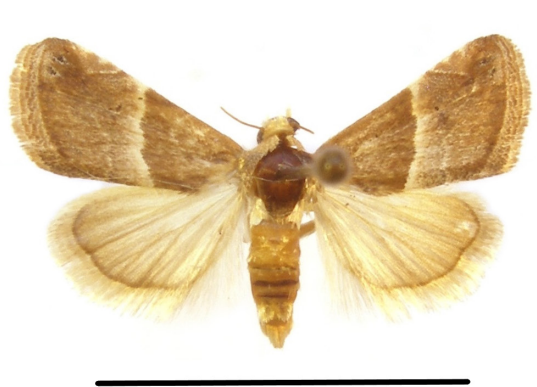

USSR, Turkmenla, Kara-Kum desert, $100 \mathrm{~m}, 42 \mathrm{~km} \mathrm{~N}$ of

Ashkhabad, $58^{\circ} 33^{\prime} \mathrm{E}, 38^{\circ} 21^{\prime} \mathrm{N}$.

15.:0.1991. No. L45 leg.: A. Podlussany, L. Ronkay \& Z.

Varge

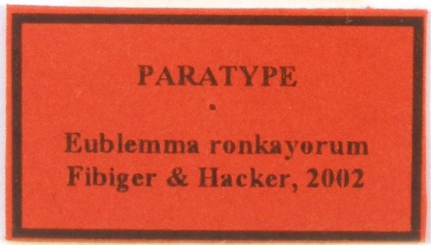

Figure 3. Museum specimens of Eublemma species with their labels from the Hungarian Natural History Museum, in dorsal view. $A=E$. pannonica (Freyer, 1840) specimen curated as "Anthophila Lenis" in the Treitschke Collection (the identification label "Pannonica" was written by I. Frivaldszky); B = E. pannonica ronkayi Katona, Tóth \& Bálint, nom n. (paratype specimen of E. panonica ronkayorum Fibiger, Zilli \& Yela, 2010); C = paratype of E. ronkayorum Fibiger \& Hacker, 2002. (scale bars $=1 \mathrm{~cm}$ ) 


\section{CONCLUSIONS}

The spelling of Eublemma pannonica (Freyer, 1840), an emblematic erebid moth species of the Pannonian fauna, has been stabilized via the citation of 37 literature references. The source of the various spellings was the original description, plus the purely technical cataloguing manner of Poole (1989), who reintroduced the original misspelling. According to Fibiger et al. (2010) and Sinev (2019), the species E. pannonica is a Mediterranean-Asiatic represented by two subspecies: (1) ssp. pannonica, distributed from Mongolia (?) via the Kazakh-Russian steppe to the Carpathian Basin; and (2) ssp. ronkayi, from Uzbekistan, Turkmenistan, and the Caucasus (Dagestan), via NW Iran and Anatolia to the Mediterranean region, including Crete, and NW Africa (FIBIGER et al. 2010). The species E. ronkayorum Fibiger \& Hacker, 2002 is an exclusively Central Asiatic species (EBERT \& HACKER 2002).

Acknowledgements - We express our most sincere thanks for the comments made on our manuscript by Balázs Benedek (Budapest, Hungary), John B. Heppner (Gainesville, USA), Tomasz Pyrcz (Kraków, Poland), László Ronkay (Budapest, Hungary), Aidas Saldaitis (Vilnius, Lithuania) and Alberto Zilli (London, UK).

\section{REFERENCES}

Abafi-Aigner L. 1899: A lepkészet története Magyarországon. - Királyi Magyar Természettudományi Társulat, Budapest, 202 pp.

A BAFI-Aigner L. 1907: Magyarország lepkéi tekintettel Európa többi országának lepkefaunájára. A Berge-féle lepkekönyv képeivel. - Magyar Királyi Természettudományi Társulat, Budapest, XXXII +137 pp, 51 t.

Abafi-Aigner L., PÁvel J. \& Uhry n N. 1896: Fauna Regni Hungariae. Animalium Hungariae Hucusque Cognitorum Enumeratio Systematica in Memoriam Regni Hungariae Mille Abhinc Annis Constituti. III. Arthropoda. Insecta. Lepidoptera. Ordo Lepidoptera. - Királyi Magyar Természettudományi Társulat, Budapest, $82 \mathrm{pp}$.

A. Aigner L. 1901: Thalpochares pannonica Frr. - Rovartani lapok 8(8): 153-155.

Aigner L. 1868: Aus den charakterischen Angaben zur Fauna Ungarns nach Emerich Frivaldszky. Ungarische Revue. Beiträge zur Kenntniß der Vergangenheit und Gegenwart Ungarns 1: $48-68$.

Anikin V. V., SAChov S. A. \& Zolotuhin V. V. 2017: „Fauna Lepidopterologica Volgo-Uralensis” from P. Pallas to Present Days. - Museum Witt Munich \& Research Center Vilnius, Proceedings of the Museum Witt Munich, Volume 7, 693 pp. 
Anonymus [1842]: Catalog der europäischer Schmetterlinge der Friedrich Treitschke in Wien. [Pesth], 7 pp.

Bálint Zs., Gubányi A. \& Katona G. 2014: A life for Noctuidae. The Owlet Moths of Márton Hreblay (1963-2000). Names, specimens and types. - Hungarian Natural History Museum, Budapest, $270 \mathrm{pp}$.

Bálint Zs. \& Zolotuhin V. V. 2017: Names of Volgo Ural Region Lepidoptera proposed by Christian Friedrich Freyer and their type specimens, pp 424-431. In ANikin V. V., SAchov S. A. \& Zolotuhin V. V.: „Fauna Lepidopterologica Volgo-Uralensis” from P. Pallas to Present Days. - Museum Witt Munich \& Research Center Vilnius, Proceedings of the Museum Witt Munich, Volume 7,693 pp.

Boisduval J. B. 1840: Genera et Index Methodicus, Europaeorum Lepidopterorum. (Pars I. Sistens Papiliones, Sphinges, Noctuas). - Roret, Paris, 238 pp.

Ebert G. \& Hacker H.H. 2002: Beitrag zur Fauna der Noctuidae des Iran: Verzeichnis der Bestände im Staatlichen Museum für Naturkunde Karlsruhe, taxonomische Bemerkungen und Beschreibung neuer Taxa (Noctuidae, Lepidoptera). - Esperiana Buchreihe zur Entomologie 9: 237-409.

Eversmann E. 1844: Fauna lepidopterologica Volgo-Uralensis. - Casani, xiv + 633 pp.

Fibiger M. \& HaCker H. 1991: Systematic List of the Noctuidae of Europe. - Esperiana Buchreibe zur Entomologie 2: 1-109.

Fibiger M., Ronkay L., Yela J. L. \& Zilli A. 2010: Noctuidae Europaeae. Volume 12. Rivulinae, Boletobiinae, Hypenodinae, Araeopteroninae, Eublemminae, Herminiinae, Hypeninae, Phytometrinae, Euteliinae, and Micronoctuidae. Including Supplement to Volumes 1-11; And for some new species, in cooperation with M. Dvorak, O. Pekarsky, S. Simonyi \& J. Šumpich. Entomological Press, Sorø, $451 \mathrm{pp}$.

Forster W. \& Wohlfahrt Th. A. 1971: Die Schmetterlinge Mitteleuropas. Eulen (Noctuidae). Franckh'sche Verlagshandlung, Stuttgart. [ii] + 329 pp, 32 pls.

Freyer C. F. 1840: Neuere Beiträge zur Schmetterlingskunde mit Abbildungen nach der Natur. Band 4. - Verlag Rieger, Augsburg, 167 pp, 96 pls.

FrivaldszKy I. 1859: Hazánk faunájára vonatkozó adatok, és a Puszta-peszéri erdő. - $A$ Magyar Tudós Társaság Évkönyvei, Buda 9: 19-28.

FRIVAldSZKY I. 1865: Jellemző adatok Magyarország faunájáboz. Magyar Tudományos Akadémia Évkönyve XI. - Eggenberger, Pest, 274 pp, XIII pls.

HaCker H. 1989: Die Noctuidae Grichenlands. Mit einer Übersicht über die Fauna des Balkanraumes (Lepidoptera, Noctuidae). - Herbipoliana. Buchreihe zur Lepidopterologie. Band 2. Dr. Ulf EItschberger, Markleuthen, $589+$ xii pp.

HERRICH-SCH ÄFFER G. A. W. 1843: Systematische Bearbeitung der Schmetterlinge von Europa, zugleich als Text, Revision und Supplement zu Jakob Hübner's Sammlung europäischer Schmetterlinge, Zweiter Band. Die Schwärmer, Spinner und Eulen. -Regensburg, in Commission bei G. J. Mainz, 450 pp.

HeydenReich H. H. 1851: Lepidopterorum Europaeorum Catalogus Methodicus. Systematiches Verzeichniss der Europaeischen Schmetterlinge. - Verlag von Julius Klinkhardt, Lepizug, $130 \mathrm{pp}$. 
Hruby K. 1964: Prodromus lepidopter Slovenska. Prodromus Lepidopterorum Slovaciae. Vydavetelstvo Slovenskej Akadémie Vied, Bratislava, 962 pp.

International Commission on Zoological Nomenclature 1999: International Code of Zoological Nomenclature. Fourth Edition adopted by the International Union of Biological Sciences. - Tipografia La Garangola, Padova, XXIX + 273 pp.

Kemal M., Kızilda $\breve{G}$ S. \& KoçAK A. Ö. 2020: Annotated list of the Heterocera (Lepidoptera) of Anamur district (İçel Province, South Turkey) with description of a new species. - Priamus 19: $1-72$.

KoçaK A. Ö. \& Kemal M. 2018: Synonymous and distributional list of the species of the Lepidoptera of Turkey. - Centre for Entomological Studies Ankara, Memoirs 8: 1-487.

[Kovács L.] BALOGH J. 1950: Lepkék. pp 521-618. - In MóczÁR L. (szerk.): Állathatározó. I-II. - Közoktatásügyi Kiadóvállalat, Budapest, 798 + 344 pp.

Kovács L. 1955: The Macrolepidoptera characteristic to our sandy district. - Annales historiconaturales Musei nationalis hungarici 47: 327-342.

LeDerer J. 1857: Die Noctuiden Europas mit Zuziehung einiger bisher meist dazu gezählter Arten des asiatischen Russlands's, Kleienasien's, Syrien's und Labrador's. Systematisch bearbeitet. bei Friedrich Manz, Wien, xv + 251 pp, 4 pls.

Olivier A. 2000: Christian Friedrich Freyer's "Neuere Beiträge zur Schmetterlingskunde mit Abblildungen nach der Natur": an analysis, with new data on its publication dates (Insecta, Lepidoptera). - Beiträge zur Entomologie 50: 407-486.

Parenzan P., Russo P. \& Bella S. 2002: Eublemma pannonica (Freyer, 1840) (Lepidoptera, Noctuidae), specie nuova per la fauna di Sicilia e italiana (Contributi alla conoscenza della lepidotterofauna siciliana IX). - Entomologica 36: 165-169.

Poole R. W. 1989: Lepidopterorum Catalogus. New Series. Fascicle 118. Noctuidae. - CRC Press, $1314 \mathrm{pp}$.

RÁ Kosy L. 1996: Die Noctuidae Rumäniens (Lepidoptera Noctuidae). - Stapfia 46: 1-648.

Ronkay L. 1997: Nemzeti biodiverzitás-monitorozó rendszer VII. Lepkék. - Magyar Természettudományi Múzeum, Budapest, 71 pp.

Ronkay L. 2014: Appendix 3. Nomenclatorial revision of names used in the Hreblay collection and the catalogue, pp 215-231. In BÁlint Zs., Gubányi A. \& Katona G.: A life for Noctuidae. The Owlet Moths of Márton Hreblay (1963-2000). Names, specimens and types. Hungarian Natural History Museum, Budapest, $270 \mathrm{pp}$.

Sinev S. Y. (еd.) 2019: Каталог чешуекрыльх (Lepidoptera) России. Издание второе. (Cataloguе of the Lepidoptera of Russia. Edition 2.) - Zoological Institute RAS, St. Petersburg, 448 pp.

SPUler A. 1908: Die Schmetterlinge Europas. Band I. - E. Schweizerbartsche Verlagsbuchhandlung, Stuttgart, $385 \mathrm{pp}$.

Staudinger O. \& Rebel H. 1901: Catalog der Lepidopteren des Palaearctischen Faunengebietes. I. Theil: Famil. Papilioniodae-Hepialidae. - R. Friedländer \& Sohn, Berlin, xxx+[ii]+411 pp.

VARGA Z. 1969: Lepkék, pp 7-14, 24-153. In Móczár L. (szerk.): Állathatározó II. kötet. Tankönyvkiadó, Budapest, 758 pp + fényképek.

VARGA Z. 1989: Lepkék, pp 188-244. In RA KONCZAI Z. (editor): Vörös könyv, a Magyarországon kipusztult és veszélyeztetett növény-és állatfajok. - Akadémiai Kiadó, Budapest, 360 pp.

VARGA Z. (szerk.) 2010: Magyarország nagylepkéi. - Heterocera Press, Budapest, 253 pp. 
Warren W. 1909-1914: 2. Familie: Noctuidae, pp 1-444. In Seitz A. (ed.) Die GrossSchmetterlinge der Erde. Eine systematische Bearbeitung der bis jetzt bekannten GrossSchmetterlinge. I. Abteilung: Die Gross-Schmetterlinge des Palaearktischen Faunengebietes. 3. Band: Die eulenartigen Nachtfalter. - Alfred Kernen Verlag, Stuttgart, iii + 511 pp.

\title{
Jegyzetek az Eublemma pannonica (Freyer, 1840) nevezéktanáról: helyesbítés és új alfaji név (Lepidoptera: Erebidae, Eublemminae)
}

\author{
Katona Gergely, Tóth Balázs, Bálint Zsolt
}

Magyar Természettudományi Múzeum, Állattár, Budapest VIII, Baross utca 13, H-1088.

E-mail:katona.gergely@nhmus.hu,toth.balazs@nhmus.hu,balint.zsolt@nhmus.hu

Összefoglalás - Az Eublemma pannonica (Freyer, 1840) nevủ bagolylepke a Pannon régió különleges faja. Az eredeti leírásban a fajcsoport-nevet kétféleképpen betűzte a szerző: (1) panonica és (2) pannonica. Az első változat egészen 1989-ig nem volt használatban, de az 1989-ben megjelent Robert W. Poole által szerkesztett Noctuidae katalógus után újra megjelent az irodalomban. Ezért helyesbítésre szorul. A másik, helyes névváltozat egészen 1989-ig volt általános használatban, amit a felsorolt irodalmi hivatkozások bizonyítanak. Az Eublemma panonica ronkayorum Fibiger, Zilli \& Yela, 2010 név az Eublemma ronkayorum Fibiger \& Hacker, 2002 fiatalabb társneve, ezért a fiatalabb taxon számára a behelyettesítő Eublemma pannonica ronkayi új nevet javasoljuk. Három ábrával.

Kulcsszavak - Freyer Christoph, Frivaldszky Imre, helyettesítő név, Kindermann Albert, Szerémség, Treitschke Friedrich

\section{ÁBRAMAGYARÁZATOK}

1. ábra. Részletek Freyer (1840) könyvéből, amelyek bizonyítják az Eublemma pannonica faj fajcsoport névének kétféle írásmódját. A = A „Noct. Panonica” leírása a 67. oldalon; B = A 330. színes tábla 3. és 4. képe, és az ábramagyarázatok (a cikk tárgyának szempontjából fontos szavak pirossal aláhúzva) (forrás: Biodiversity Heritage Library) 
2. ábra. Múzeumi Eublemma pannonica (Freyer, 1840) példányok és céduláik a Frivaldszkygyüjteményből (Magyar Természettudományi Múzeum). A = lepke (felülnézet); $\mathrm{B}=$ hernyó (ugyanaz a példány felül és oldalnézetből) (méretlécek: $1 \mathrm{~cm}$ )

3 ábra. Múzeumi Eublemma példányok és céduláik a Magyar Természettudományi Múzeum gyüjteményéből (mind felülnézetben). A = E. pannonica (Freyer, 1840) példány, a Treitschkegyüjteményben „Anthophila Lenis” név alatt őrizve (a „Pannonica” határozó cédulát Frivaldszky Imre írta); B = E. pannonica ronkayi Katona, Tóth \& Bálint, új név (az E. panonica ronkayorum Fibiger, Zilli \& Yela, 2010 egyik paratípus példánya); C = az E. ronkayorum Fibiger \& Hacker, 2002 egyik paratípus példánya. (méretlécek $=1 \mathrm{~cm}$ ) 